\title{
ANALISIS PENERAPAN STANDAR AKUNTANSI SYARIAH PSAK NO.101 TERHADAP PENGELOLAAN TRANSAKSI KEUANGAN DI BANK SYARIAH (STUDI PADA BANK BRI SYARIAH CABANG LHOKSEUMAWE)
}

\author{
Nur Afni Yunita ${ }^{1}$ \\ ${ }^{1}$ Prodi Akuntansi Fakultas Ekonomi dan Bisnis Universitas Malikussaleh Lhokseumawe \\ 1nurafni.yunita@unimal.ac.id
}

\begin{abstract}
The purpose of this study was to find out how the application of sharia accounting standards to the management of financial transactions and comparison of application of sharia accounting standards applied by PT. Bank BRI Syariah, Branch of Lhokseumawe with PSAK NO.101. The object of this research was PT. Bank BRI Syariah, Branch of Lhokseumawe. This research was conducted by using qualitative descriptive method through a case study at PT. Bank BRI Syariah, Branch of Lhokseumawe. The data used were primary data in the form of an interview. The results of this study indicated that there was no significant difference between the implementation of sharia accounting standards applied by Bank BRI Syariah, Branch of Lhokseumawe with PSAK NO.101.
\end{abstract}

Keywords: Implementation of accounting standards, PSAK NO.101, Management of Financial Transactions.

\section{PENDAHULUAN}

Penyajian Laporan

Keuangan Syariah (disebut PSAK 101) merupakan penetapan dasar penyajian laporan keuangan bertujuan umum untuk entitas syariah. Pernyataan ini mengatur persyaratan penyajian laporan keuangan, struktur laporan keuangan, dan persyaratan minimal isi laporan keuangan atas transaksi syariah. (Adnan M.Akhyar,2011) mendefinisikan Akuntansi Syariah sebagai praktek akuntansi yang bertujuan untuk membantu tercapainya transaksi yang bersifat adil dalam lingkup sosial ekonomi. Pengertian dari standar akuntansi syariah pada dasarnya hampir sama dengan pengertian standar akuntansi secara umum,akan tetapi standar akuntansi syariah lebih mengutamakan kearah pola pertangung jawaban yang menuju keadilan,kebenaran antar sesama sesuai dengan syariat islam. Pernyataan Standar Akuntansi Keuangan No.59 (2002) meliputi:

a) Pengakuan terdiri dari pengakuan mudharabah,musyarakah,salam dan salam pararel,istisna dan istisna pararel,ijarah dan ijarah muntahiyyah bittamlik dan pengakuan Al-qadr.

b) Pencatatan terdiri dari pencatatan mudharabah,musyarakah,salam dan salam pararel,isthisna dan isthisna pararel,ijarah dan ijarah munthahiyyah bittamlik dan pencatatan Al-qardh.

c) Pengungkapan terdiri dari pengungkapan mudharabah,musyarakah,salam dan salam pararel,ijarah dan ijarah muntahiyyah bittamlik dan pengungkapan Al-qar

Dalam pasal 1 ayat 7 undang-undang No.21 Tahun 2008 tentang perbankan syariah menjelaskan: "Bank syariah merupakan bank yang menjalankan kegiatan usahanya bersasarkan prinsip syariah dan menurut jenisnya terdiri dari bank umum syariah dan bank pembiayaan syariah"
Bank syariah adalah bank yang berazazkan antara lain kemitraan keadilan transparansi dan universal serta memiliki falsafah mencari keridhaan Allah untuk memperoleh kebajikan dunia dan akhirat. (Syarifudin,2005) Pengelolaan transaksi keuangan sangat di perlukan dalam bank syariah untuk mengungkapkan laporan atau informasi kepada pihak yang memerlukan baik dari pihak bank maupun nasabah oleh karena itu penegelolaan transaksi keuangan pada bank syariah harus sesuaidan berpedoman kepada Standar akuntansi syariah salah satunya dari PSAK No.101.Bank syariah yang berdasarkan pada prinsip-prinsip islam begitu menekankan masalah pencatatan transaksi sebagai mana dalam Al-quran yang menjadi pegangan orang muslim.

Pada dasarnya pengelolaan transaksi keuagan pada bank syariah tidak jauh berbeda pada teknik akuntansi pada umumnya pada bank konvensional dimulai dari klasifikasi transaksi keuagan,dokumendokumen yang di perlukan,sampai pada pengawasan pengelolaan transaksi keuagan. Wasila (2002) Klasifikasi transaksi keuagan pada bank syariah pada prinsipnya dapat di klasifikasikan dalam lima prinsip yaitu: a. Prinsip titipan, b. prinsip bagi hasil, c. prinsip jual beli, d. Prinsip sewa, e. Prinsip jasa. Adapun dokumen yang di gunakan dalam pengelilaan transaksi keuagan antara lain adalah sebagai berikut: Dokumen produk dana,dokumen produk pembiayaan dan dokumen produk jasa. (Muhammad,2002). Pengawasan pengelolaan transaksi keuangan merupakan kepentingan utama bagi manajemen puncak adalah kelancaran operasi dalam bank. Pengawasan yang di lakukan oleh para manajer akan sangat di pengaruhi pada kepastian tercapai tidaknya harapan mereka dalam pengambilan keputusan yang lebih baik beberapa hal hal yang perlu di perhatikan dalam kaitannya dengan pengawasan transaksi keuangan di antaranya adalah 
proses pengawasan,sistem informasi manajemen dan program audit internal (Muhammad,2002).

Kesuksesan suatu bank syariah di tentukan dengan tingkat kepercayaan publik terhadap kekuatan finansial bank yang bersangkutan dan kepercayaan terhadap kesesuaian terhadap operasioanal bank dengan sistem syariah islam kepercayaan ini terutama kepercayaan yang di berikan oleh para depositor dan investor di mana keduanya termasuk stake holder utama sistem perbankan. Salah satu sumber utama untuk meraih kepercayaan publik adalah tingkat kualitas informasi yang di berikan kepada publik dimana bank syariah harus mampu meyakinkan publik bahwa ia memiliki kemampuan dan kapasitas di dalam mencapai tujuan-tujuan finansial maupun tujuan-tujuan yang sesuai dengan syariat islam.

Berdasarkan kegiatan pengamatan sebelumnya yang dilakukan oleh peneliti penerapan akuntansi Syariah pada Bank BRI Syariah cabang lhokseumawe masih di temukan beberapa permasalahan antara lain yaitu: Masih minimnya sumberdaya manusia yang ahli akuntansi syariah, prinsip bagi hasil memerlukan kejujuran dari nasabah maupun pengelola bank,sistem pengawasan dari dewan pengawas syariah yang belum optimal dan Pemanfaatan teknologi informasi yang belum optimal. Fenomena di atas mengambarkan khususnya pada poin mengenai prinsip bagi hasil memerlukan kejujuran antara nasabah dan pengelola bank menyangkut tentang pengelolaan keuangan Bank BRI Syariah cabang Lhokseumawe Harus berpedoman pada PSAK No.101 karena pada PSAK No.101 mengatur tentang (perlakuan, pengukuran, penyajian, pengungkapan) transaksi khususnya yang berkaitan dengan aktivitas bank syariah. (Rina Nuraina dkk,2015). Penerapan PSAK No.101 terhadap pengelolaan transaksi keuagan fenomena yang menarik karena telah diteliti oleh beberapa peneliti. Salah satunya menurut Sri Fadillah dkk (2015), dalam penelitiannya, disimpulkan bahwa penerapan PSAK No.101 berpengaruh signifikan terhadap pengelolaan transaksi keuangan sebesar $71.4 \%$.

Penelitian R.Ait novianti dan dwi utari (2009) menyatakan bahwa variabel standar akuntansi syariah berhubungan kuat dan positif terhadap pengelolaan transaksi keuagan sebesar $50.5 \%$ dan sisanya $49.5 \%$ kontribusi faktor lain. Namun hasil penelitian tersebut inkonsisten dengan penelitian yang dilakukan oleh Masliana (2011) yang menyatakan bahwa variabel standar akuntansi syariah masih belum sepenuhnya berpengaruh pada transaksi keuangan bank syariah karena kurangnya pengawasan dari DPS (dewan pengawas syariah) yang hanya berfokus pada bank syariah pusat. Penelitian Inayah (2011) menyatakan bahwa tidak semua kontrak pembiayaan bank syariah sesuai dengan hukum islam.

Berdasarkan beberapa hasil dari penelitan sebelumnya maka penulis tertarik untuk meneliti kembali mengenai fenomena Penerapan standar akuntansi syariah PSAK No.101 khusunya pada Pengelolaan transaksi keuangan Namun terdapat beberapa perbedaan yaitu, pada penelitian ini objek penelitian dan Periode waktu penelitian yang digunakan adalah tahun 2017.

\section{LANDASAN TEORITIS}

\section{Standar Akuntansi syariah}

Standar Akuntansi Syariah (SAS) adalah Pernyataan Standar Akuntansi Keuangan (PSAK) Syariah yang ditujukan untuk entitas yang melakukan transaksi syariah baik entitas lembaga syariah maupun lembaga non syariah. Pengembangan SAS dilakukan dengan mengikuti model SAK umum namun berbasis syariah dengan mengacu kepada fatwa MUI. Berikut ini pengertian Standar akuntansi syariah yang penulis kutip dari beberapa sumber diantaranya. Adnan M Akhyar (2005) Akuntansi syariah bidang di dalam ilmu akuntansi yang lebih menekankan pada dua hal yaitu pelaporan dan akuntanbilitas.

\section{Tujuan Akuntansi Syariah}

menurut Kusmawati (2005) berikut ini penjelasan dari tujuan akuntansi syariah.

1. Perlindungan Harta (Hifzul Maal)

Hal ini menjelaskan bahwa ketika

menuliskan mengenai uang dan harta merupakan kebutuhan agar dapat menjaga harta tersebut serta menghindari dan menghilangkan rasa keragu.

2. Eksistensi Pencatatan Ketika Terdapat Perselisihan

Pencatatan transaksi keuangan pada harta benda yang dimiliki, merupakan sebuah tujuan agar dapat memberikan kesaksian yang real dan kuat bila terjadi perselisihan pada transaksi atau harta.

3. Membantu Mengambil Keputusan

Dengan tidak adanya data-data yang lengkap dalam catatan keuangan maka dapat membuat pengusaha bisnis kesulitan dalam mengungkapkan pemikiran yang tepat dan benar ketika mengambil sebuah keputusan yang bijak.

4. Menentukan dan Menghitung Hak-hak Berserikat

Di dalam perdagangan pastinya terdapat akad dengan jenis perserikatan diantara modal dan keahlian serta nama baik.

\section{Menentukan Hasil Usaha Yang Akan Dizakatkan}


Ketika akan menentukan perhitungan untuk zakat, tentunya anda harus mengetahui hasil yang anda dapatkan baik dalam hal keuntungan maupun kerugian. Dasar tersebut akan membantu anda untuk menghitung dengan mudah jumlah zakat yang harus dikeluarkan atas harta yang anda miliki.

\section{Menentukan Imbalan, Sanksi, Dan Balasan}

Tujuan dari akuntansi Islam tentunya harus mempresentasikan tujuan akuntansi yang memang sesuai pada tujuan mumalah tersebut.

\section{Teori Transaksi dan akad}

Transaksi merupakan suatu kegiatan yang diakukan seseorang yang menimbulkan perubahan terhadap harta atau keuangan yang dimiliki baik itu bertambah ataupun berkurang. Dalam akuntansi syari'ah transaksi dapat dikelompokkan menjadi dua, yaitu :

1. Transaksi yang halal adalah semua transaksi yang diperbolehkan oleh syariat islam

2. Transaksi yang haram

transaksi yang haram adalah kebalikannya yaitu dilarang oleh syariat islam.

Akad berasal dari lafal Arab al-'aqd yang berarti perikatan, perjanjian atau permufakatan (alittifaq). Jadi akad adalah suatu perikatan, perjanjian yang ditandai dengan adanya pernyataan melakukan ikatan (ijab) dan pernyataan menerima ikatan (qabul) sesuai dengan syariat islam. Sedangkan rukun akad terdiri dari :

1. pernyataan untuk mengikatkan diri (sighat al'aqd)

2. pihak yang berakad (al-muta'aqidain)

3. objek akad (al-ma'qud'alaih)

\section{Teori Pengelolaan Transaksi Keuangan}

Transaksi adalah situasi atau kejadian yang melibatkan unsur lingkungan dan mempengaruhi posisi keuangan. Setiap transaksi harus dibuatkan keterangan tertulis seperti faktur atau nota penjualan atau kwitansi dan disebut dengan Bukti Transaksi.

(Syarifudin, 2005) Pengelolaan keuangan adalah kegiatan yang dilakukan oleh seorang pemimpin dalam menggerakan para pejabat yang bertugas dalam bidang keuangan untuk menggunakan fungsi manajemen, meliputi perencanaan atau penganggaran, pencatatan, pengeluaran serta pertanggung jawaban. Dalam kegiatan pengelolaan keuangan tidak terlepas dari kegiatan berupa perencanaan, penggunaan, pencatatan, dan pelaporan pertanggung jawaban.

\section{Tujuan Pengelolaan Transaksi Keuangan}

Tujuan pengelolaan transaksi keuagan Untuk menyiapkan suatu laporan keuangan yang akurat agar dapat dimanfaatkan oleh para manajer, pengambil kebijakan, dan pihak berkepentingan lainnya, seperti pemegang saham, kreditur, atau pemilik. Akuntansi keuangan adalah suatu cabang dari akuntansi dimana informasi keuangan pada suatu bisnis dicatat, diklasifikasi, diringkas, diinterpretasikan, dan dikomunikasikan.

Setiap lembaga keuagan bank ataupun non bank dalam menjalankan kegiatan usahanya akan melakukan suatu transaksi keuagan. Transaksi keuagan sangat di perlukan dalam bank syariah untuk mengungkapkan setiap lembaga laporan atau informasi kepada pihak yang memerlukan baik dari pihak bank maupun nasabah.

\section{Fungsi Pengelolaan Transaksi Keuangan}

1. Membantu pihak perusahaan mengetahui laba yang di peroleh

2. Memudahkan perusahaan unruk menghitung dan menentukan hak dari berbagai pihak yang terlibat baik internal maupun eksternal.

3. Sebagai alat untuk menyediakan informasi yang berguna bagi manajemen.

4. Mengelola (mengendalikan) dan mengawasi aktivitas dalam perusahaan.

\section{Komponen laporan keuangan}

1. Neraca

2. Laporan laba rugi

3. Laporan arus kas

4. Laporan perubahan ekuitas

5. Laporan sumber dan pengunaan dana zakat

6. Laporan sumber dan pengunaan dana kebijakan

7. Catatan atas laporan keuagan

\section{Penyajian Laporan Keuangan Berdasarkan SAK ETAP}

Menurut SAK ETAP (Paragraf 3.2). Laporan keuangan menyajikan dengan wajar posisi keuangan, kinerja keuangan, dan arus kas suatu entitas. Penyajian wajar mensyaratkan penyajian jujur atas pengaruh transaksi, peristiwa, dan kondisi lain yang sesuai dengan definisi dan kriteria pengakuan aset, kewajiban, penghasilan dan beban yang dijelaskan dalam Bab 2 Konsep dan Prinsip Pervasif.

\section{METODE PENELITIAN}

Sumber data pada penelitian ini terdiri dari data primer. Teknik analisis data yang digunakan dalam penelitian ini adalah teknik analisis deskriftif kualitatif yaitu dengan cara dengan cara menggambarakan keadaan objek penelitian yang seseungguhnya untuk mengetahui dan menganalisis tentang permasalah yang di hadapi oleh objek penelitian yaitu apakah penerapan standar akuntansi syariah PSAK No.101 pada bank BRI Syariah cabang lhokseumawe sudah sesuai atau belum sesuai. 


\section{Metode Analisis Data}

Analisis data dalam penelitian ini menggunakan metode kualitatif dimana data yang berbentuk kata, kalimat, skema dan gambar akan dikumpulkan, dikelompokkan, diuraikan dan dianalisis sehingga dapat memberikan keterangan lengkap atas gambaran mengenai masalah yang dihadapi.

\section{HASIL PENELITIAN DAN PEMBAHASAN} Penerapan Standar Akuntansi Syariah berdasarkan PSAK NO.101

\section{Mudharabah}

Bank BRI Syariah Cabang Lhokseumawe pada saat pemberian pembayaran Mudharabah dalam bentuk aktiva non kas pada nasabah dana dan pembiayaan di berikan secara bertahap di akui pada setiap pembayaran atau penyerahan.

a. Pada saat awal penandatangannan akad pada 1 januari 2017

\begin{tabular}{|l|c|c|}
\hline Keterangan & Debed & Kredit \\
\hline Kas Nasabah & Rp.1000.000 & \\
\hline $\begin{array}{l}\text { Pendapatan } \\
\text { Administrasi }\end{array}$ & & Rp. 1000.000 \\
\hline
\end{tabular}

b. Pada 10 januari 2017 pencairan pembiayaan

\begin{tabular}{|l|c|c|}
\hline Keterangan & Debed & Kredit \\
\hline $\begin{array}{l}\text { Investasi } \\
\text { Mudharabah }\end{array}$ & Rp.10.000.000 & \\
\hline Kas/Nasabah & & Rp.10.000.000 \\
\hline
\end{tabular}

c. Pada tanggal 31 januari 2017 hasil perdagangan:

Pendapatan : Rp. 1000.000

Biaya-biaya : Rp. 800.000

d. Di akhir periode ketika akan di lakukan perhitungan bagi hasil,maka akun pendapatan harus di tutup dengan melakukan jurnal:

\begin{tabular}{|l|c|c|}
\hline Keterangan & Debed & Kredit \\
\hline Pendapatan & Rp.10.000 & \\
\hline Biaya & & Rp. 800.000 \\
\hline $\begin{array}{l}\text { Pendapatan yang } \\
\text { belum di bagi }\end{array}$ & & Rp.200.000 \\
\hline
\end{tabular}

Perhitungan bagi laba sesuai nisbah

Nasabah $=75 \% \times($ Rp. 1000.000-RP. 800.000) $=$ Rp. 150.000

Bank BRI Syariah $=25 \% \times$ (Rp. 1000.000-RP. $800.000)=50.000$

e. Jurnal pemilik dana PT. Bank BRI Syariah cabang Lhokseumawe

\begin{tabular}{|l|l|c|}
\hline Keterangan & \multicolumn{1}{|c|}{ Debed } & Kredit \\
\hline Kas & Rp.9.800.000 & \\
\hline $\begin{array}{l}\text { Penyisihan } \\
\text { kerugian }\end{array}$ & Rp.200.000 & \\
\hline $\begin{array}{l}\text { Investasi } \\
\text { Mudharabah }\end{array}$ & & Rp.1000.000 \\
\hline
\end{tabular}

f. Jurnal pengelola dana

\begin{tabular}{|l|c|c|}
\hline Keterangan & Debed & Kredit \\
\hline Dana Syirkah & Rp. 1000.000 & \\
\hline Kas & & Rp.9.800.000 \\
\hline
\end{tabular}

\begin{tabular}{|l|l|l|}
\hline $\begin{array}{l}\text { Penyisihan } \\
\text { Kerugian }\end{array}$ & & Rp.200.000 \\
\hline
\end{tabular}

\section{Musyarakah}

Bank BRI Syaroiah Cabang Lhokseumawe dan nasabah bekerja sama mengenai sistem bagi hasil dengan rincian jumlah investasi yang telah di sepakati di awal berdasarkan jenis akad musyarakah.

a. Pengakuan dan pengukuran saat awal akad di sepekati pada 2 febuari 2017

\begin{tabular}{|l|c|c|}
\hline Keterangan & Debed & Kredit \\
\hline $\begin{array}{l}\text { Pembiayaan } \\
\text { Musyarakah }\end{array}$ & Rp.60.000.000 & \\
\hline $\begin{array}{l}\text { Rekening } \\
\text { giro nasabah }\end{array}$ & Rp.600.000.000 & Rp.60.000.000 \\
\hline Kas & & Rp.600.000.000 \\
\hline $\begin{array}{l}\text { Pendapatan } \\
\text { Administrasi }\end{array}$ & & \\
\hline
\end{tabular}

b. Pengakuan dan pengukuran saat penyerahan musyarakah oleh PT. Bank BRI Syariah Cabang Lhokseumawe pada 12 febuari 2017.

\begin{tabular}{|l|c|c|}
\hline Keterangan & Debed & Kredit \\
\hline $\begin{array}{l}\text { Investasi } \\
\text { Musyarakah }\end{array}$ & Rp.35.000.000 & \\
\hline $\begin{array}{l}\text { Kas Rekening } \\
\text { Nasabah }\end{array}$ & & Rp.35.000.000 \\
\hline
\end{tabular}

c. pembiayaan musyarakah pada 2 maret 2017

\begin{tabular}{|l|c|c|}
\hline Keterangan & Debed & Kredit \\
\hline $\begin{array}{l}\text { Investasi } \\
\text { Musyarakah }\end{array}$ & Rp.25.000.000 & \\
\hline Kas/Nasabah & & Rp.25.000.000 \\
\hline $\begin{array}{l}\text { Kewajiban } \\
\text { komitmen } \\
\text { pembiayaan }\end{array}$ & Rp.25.000.000 & \\
\hline $\begin{array}{l}\text { Poslawan } \\
\text { komitmen } \\
\text { pembiayaan }\end{array}$ & & Rp.25.000.000 \\
\hline
\end{tabular}

Realisasi laba bruto usaha Nasabah selama $2 \mathrm{x}$ panen di laporkan pada 2 mei 2017 dan 2 agustus 2017

\begin{tabular}{|l|c|c|}
\hline Masa Panen 1 & Rp. 14.000.000 & 2 mei \\
\hline Masa Panen 2 & Rp. 14.000.000 & 12 Agustus \\
\hline
\end{tabular}

d. Pengakuan dan pengukuran bagi hasil 2 mei 2017

\begin{tabular}{|l|c|c|}
\hline Keterangan & Debed & Kredit \\
\hline $\begin{array}{l}\text { Rekening } \\
\text { Nasabah }\end{array}$ & Rp.3.500.000 & \\
\hline $\begin{array}{l}\text { Penetapan Bagi } \\
\text { hasil }\end{array}$ & & Rp.3.500.000 \\
\hline
\end{tabular}

e. Penerimaan bagi hasil yang waktu pembayarannya berbeda dengan tangal laporan bagi hasil pada 2 agustus 2017 dan 12 agustus 2017

\begin{tabular}{|l|l|l|}
\hline Keterangan & Debed & Kredit \\
\hline $\begin{array}{l}\text { Tagihan } \\
\text { Pendapatan } \\
\text { Bagi Hasil }\end{array}$ & Rp.4000.000 & \\
\hline $\begin{array}{l}\text { Penetapan bagi } \\
\text { hasil }\end{array}$ & & Rp.4000.000 \\
\hline $\begin{array}{l}\text { Kas/Rekening } \\
\text { Nasabah }\end{array}$ & Rp.4000.000 & \\
\hline
\end{tabular}




\begin{tabular}{|l|l|l|}
\hline $\begin{array}{l}\text { Tanguhan } \\
\text { pendapatn bagi } \\
\text { hasil }\end{array}$ & Rp.4000.000 \\
\hline
\end{tabular}

f. Saad akad berakhir pada 10 mei 2017

\begin{tabular}{|l|c|c|}
\hline Keterangan & Debed & Kredit \\
\hline $\begin{array}{l}\text { Kas/Rekening } \\
\text { Nasabah }\end{array}$ & Rp.60.000.000 & \\
\hline $\begin{array}{l}\text { Investasi } \\
\text { musyarakah }\end{array}$ & & Rp.60.000.000 \\
\hline
\end{tabular}

\section{Ijarah}

Biaya perbaikan untuk objek sewa di akui pada saat terjadi akad, Jika penyewa melakukan perbaikan rutin objek sewa di akui sebagai beban.

Tanggal 02 september 2017 di sepakati transaksi antara PT. Bank BRI Syariah Cabang Lhokseumawe dengan Bapak husain atas manfaat sebuah ruko berdasarkan kesepakatan tersebut PT. Bank BRI Syariah membelikan ruko yang di inginkan oleh bapak husain dengan biaya perolehan sebesar Rp.250.000.000 Jurnal pengakuan aset ijarah:

\begin{tabular}{|l|c|c|}
\hline Keterangan & Debed & Kredit \\
\hline Aset Ijarah & Rp.250.000.000 & \\
\hline Kas & & Rp.250.000.000 \\
\hline
\end{tabular}

Aset ruko yang di sewa bapak husain memiliki umur ekonomis 10 tahun dengan metode garis lurus,nilai penyusutan pertahun Rp.25.000.000(10\% x Rp. 250.000.000) atau Rp. 2.083.333 per bulan.

\begin{tabular}{|l|c|c|}
\hline Keterangan & \multicolumn{1}{|c|}{ Debed } & Kredit \\
\hline $\begin{array}{l}\text { Beban } \\
\text { penyusutan }\end{array}$ & Rp. 2.083.333 & \\
\hline $\begin{array}{l}\text { Akumulasi } \\
\text { penyusutan }\end{array}$ & & Rp. 2.083.333 \\
\hline
\end{tabular}

Tanggal 20 oktober 2017 terjadi kerusakan atap ruko yang langsung di perbaiki oleh pihak bank seharga Rp.500.000

\begin{tabular}{|l|r|r|}
\hline Keterangan & Debed & Kredit \\
\hline $\begin{array}{l}\text { Beban perbaikan } \\
\text { aset }\end{array}$ & Rp.500.000 & \\
\hline Kas & & Rp.500.000 \\
\hline
\end{tabular}

\section{Qardh}

Pinjaman Qard yang di berikan oleh pihak PT. BRI Syariah dan dana pihak ketiga di akui sebesar jumlah yang di pinjamkan pada saat terjadinya.

Ibu mimin memiliki perhiasan seberat 10 gram dengan tingkat karat 16, harga standar emas pada 825 agustus 2017 adalah Rp. 333.141 per gram dengan jangka waktu pinjaman 30 hari atau 1 bulan. Perhitungan harga taksiran yang di lakukan oleh PT. BRI Syariah Cabang Lhokseumawe yaitu:

$\begin{array}{|ll|}\text { Maksimal pinjaman } & =90 \% \times \text { taksiran bank } \\ & 90 \% \times \text { Rp. } 333.1410 \\ & =\text { Rp. } 2.998 .269 \\ \text { Biaya administrasi } & =\text { Rp. } 20.000 \\ \text { Materai } & =\text { Rp. } 6000\end{array}$

a. Pada saat nasabah membayar administrasi pada bank

\begin{tabular}{|l|l|l|}
\hline Keterangan & \multicolumn{1}{|c|}{ Debed } & \multicolumn{1}{c|}{ Kredit } \\
\hline Kas & Rp.6000 & \\
\hline Pendapatan & & Rp.6000 \\
Administrasi & & \\
\hline
\end{tabular}

b. Pada saat bank menerima uang untuk tunai pembiayaan qardh

\begin{tabular}{|l|c|c|}
\hline Keterangan & Debed & Kredit \\
\hline Dana Qardh & Rp.2.998.269 & \\
\hline Kas Nasabah & & Rp.2.998.269 \\
\hline
\end{tabular}

c. Pada saat pelunasan uang pinjaman pembiayaan qardh dan barang gadai yang di kembalikan dengan membuat serah terima barang.

\begin{tabular}{|l|c|c|}
\hline Keterangan & \multicolumn{1}{c|}{ Debed } & Kredit \\
\hline Kas & Rp.2.998.269 & \\
\hline Piutang Qard & & Rp.2.998.269 \\
\hline
\end{tabular}


Tabel 1

Keseuaian Penerapan Standar Akuntansi PSAK No. 101 PT. Bank BRI Syriah cabang lhokseumawe

\begin{tabular}{|c|c|c|c|c|}
\hline No & Indikator & PT.Bank BRI Syariah & PSAK No.101 & $\begin{array}{c}\text { Sesuai/Tidak } \\
\text { Sesuai }\end{array}$ \\
\hline 1 & $\begin{array}{l}\text { Mudharabah } \\
\text { Pengakuan }\end{array}$ & $\begin{array}{l}\text { Pada saat Pembayaran Mudharabah } \\
\text { dalam bentuk aktiva non kas pada } \\
\text { nasabah di berikan secara bertahap } \\
\text { di oleh bank BRI Syariah yang } \\
\text { akui pada setiap pembayaran atau } \\
\text { penyerahan pada nasabah }\end{array}$ & $\begin{array}{l}\text { Ke pemilikan dana di akui } \\
\text { sebagai investasi mudharabah } \\
\text { pada saat pembayaran kas atau } \\
\text { penyerahan aset non kas pada } \\
\text { pengelola dana. }\end{array}$ & Sesuai \\
\hline & Pengukuran & $\begin{array}{l}\text { Beban yang terjadi tidak dapat di } \\
\text { akui sebagai bagian pembayaran } \\
\text { mudharabah Pada saat bagi hasil } \\
\text { tetapi di akui sebagai piutang. }\end{array}$ & $\begin{array}{l}\text { Bagi hasil yang belum di bayar } \\
\text { oleh pengelola dan di akui } \\
\text { sebagai piutang }\end{array}$ & Sesuai \\
\hline & Pencatatan & $\begin{array}{l}\text { Berpedoman pada Fatwa No.07/- } \\
\text { DSN-MUI/1V200 PSAK No.101 } \\
\text { meliputi :rician mengenai catatan } \\
\text { atas laporan keuangan dan segala } \\
\text { informasi yang di perlukan dalam } \\
\text { penyajian secara wajar }\end{array}$ & $\begin{array}{l}\text { PSAK No } 101 \text { meliputi rician } \\
\text { mengenai catatan artas laporan } \\
\text { keuangan pernyataan standar } \\
\text { akuntansi dan segala informasi } \\
\text { yang di perlukan dalam rangka } \\
\text { penyajian secara wajar. }\end{array}$ & Sesuai \\
\hline & Pengungkapan & $\begin{array}{l}\text { Kesepakatan seperti ukuran dana } \\
\text { dan pembagian aktivitas usaha } \\
\text { serta rincian jumlah investasi } \\
\text { mudharabah berdasarkan jenisnya }\end{array}$ & $\begin{array}{l}\text { Kesepakatan utama seperti } \\
\text { porsi dana dan pembagian } \\
\text { aktivitas usaha mudharabah } \\
\text { serta rincian jumlah investasi } \\
\text { mudharabah r berdasarkan } \\
\text { jenisnya. }\end{array}$ & Sesuai \\
\hline 2 & $\begin{array}{c}\text { Musyarakah } \\
\text { Pengakuan }\end{array}$ & $\begin{array}{l}\text { Bank dan nasabah bekerja sama } \\
\text { mengenai sistem bagi hasil dengan } \\
\text { rincian jumlah investasi yang telah } \\
\text { di sepakati di awal berdasarkan } \\
\text { jenis akad musyarakah. }\end{array}$ & $\begin{array}{l}\text { Porsi dana dan pembagian } \\
\text { aktivitas usaha mudharabah } \\
\text { serta rincian jumlah investasi } \\
\text { mudharabah } \\
\text { jenisnya. }\end{array}$ & Sesuai \\
\hline & Pengukuran & $\begin{array}{l}\text { Bank BRI Syariah memiliki } \\
\text { tangung jawab penuh } \\
\text { pembiayaan dalam } \\
\text { penyerahan kas terealisasi dan saat } \\
\text { pembayaran angsuran pokok dan } \\
\text { bagi hasil kepada nasabah. } \\
\text { Kemudian musyarakah } \\
\text { pendapatan,beban,keuntungan dan } \\
\text { kerugian }\end{array}$ & $\begin{array}{l}\text { Untuk Pengelolaan akad } \\
\text { musyarakah di gunakan sebagai } \\
\text { dasar penentuan bagi hasil serta } \\
\text { pengungkapan beban dan } \\
\text { keuntungan di ungkapkan } \\
\text { berdasarkan jenis. }\end{array}$ & Sesuai \\
\hline
\end{tabular}




\begin{tabular}{|c|c|c|c|c|}
\hline & Pencatatan & $\begin{array}{l}\text { Berpedoman pada Fatwa No.07/- } \\
\text { DSN-MUI/1V200 PSAK No.101 } \\
\text { meliputi :rician mengenai catatan } \\
\text { atas laporan keuangan dan segala } \\
\text { informasi yang di perlukan dalam } \\
\text { penyajian secara wajar. }\end{array}$ & 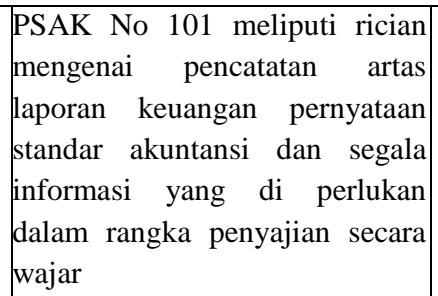 & Sesuai \\
\hline & Pengungkapan & $\begin{array}{l}\text { Pihak Bank } \text { BRI Syariah } \\
\text { mengungkapkan kesepakatan } \\
\text { utama usaha musyarakah dengan } \\
\text { memberitahukan porsi dana modal, } \\
\text { pembagian hasil keuntungan usaha } \\
\text { sesuai dengan kesepakatan awal } \\
\text { pada mitra }\end{array}$ & $\begin{array}{l}\text { Mitra mengungkap kan hal hal } \\
\text { terkait transaksi musyarakah } \\
\text { tetapi tidak terbatas isi } \\
\text { kesepakatan utama usaha } \\
\text { musyarakah seperti porsi dana } \\
\text { pembagian hasil usaha. }\end{array}$ & Sesuai \\
\hline \multirow[t]{5}{*}{3} & $\begin{array}{c}\text { Ijarah } \\
\text { Pengakuan }\end{array}$ & $\begin{array}{l}\text { Perolehan pendapatan hak atas jasa } \\
\text { sebesar biaya yang terjadi saat } \\
\text { Bank BRI Syariah melakukan } \\
\text { transaksi atau kerja sama dengan } \\
\text { pihak ketiga sebagai suplier. }\end{array}$ & $\begin{array}{l}\text { Perolehan atas aset ijarah pada } \\
\text { saat perolehan hak atas jasa } \\
\text { sebesar biaya yang terjadi } \\
\text { transaksi atau kerja sama } \\
\text { dengan pihak ketiga sebagai } \\
\text { suplier. }\end{array}$ & Sesuai \\
\hline & Pengukuran & $\begin{array}{l}\text { Pendapatan melalui penjualan } \\
\text { secara bertahap maka besar } \\
\text { pendapatan di setiap periode akan } \\
\text { menurun karena adanya pembagian } \\
\text { objek sewa pada setiap periode } \\
\text { Piutang pendapatan di ukur sebesar } \\
\text { nilai besih pada akhir periode } \\
\text { pelaporan. }\end{array}$ & $\begin{array}{l}\text { Pengukura perolehan atas aset } \\
\text { ijarah pada saat perolehan hak } \\
\text { atas jasa sebesar biaya yang } \\
\text { terjadi transaksi atau kerja } \\
\text { sama dengan pihak ketiga } \\
\text { sebagai supplier }\end{array}$ & Sesuai \\
\hline & Pencatatan & $\begin{array}{l}\text { Berpedoman pada Fatwa No.07/- } \\
\text { DSN-MUI/1V200 PSAK No.101 } \\
\text { meliputi :rician mengenai catatan } \\
\text { atas laporan keuangan dan segala } \\
\text { informasi yang di perlukan dalam } \\
\text { penyajian secara wajar. }\end{array}$ & $\begin{array}{l}\text { PSAK No } 101 \text { meliputi rician } \\
\text { mengenai catatan artas laporan } \\
\text { keuangan pernyataan standar } \\
\text { akuntansi dan segala informasi } \\
\text { yang di perlukan dalam rangka } \\
\text { penyajian secara wajar. }\end{array}$ & Sesuai \\
\hline & Pengukuran & $\begin{array}{l}\text { Rincian jumlah pinjaman qard } \\
\text { berdasarkan sumber dana dan jenis } \\
\text { pengunaan Jumlah pinjaman qard } \\
\text { yang di berikan pada pihak nasabah }\end{array}$ & $\begin{array}{l}\text { Pinjaman qard di ukur sebesar } \\
\text { jumlah dana yang di pinjamkan } \\
\text { pada saat terjadinya }\end{array}$ & Sesuai \\
\hline & Pencatatan & $\begin{array}{l}\text { Pencatatan berpedoman pada pada } \\
\text { Fatwa No.07/-DSN-MUI/1V200 } \\
\text { PSAK No.101 meliputi:rician } \\
\text { mengenai catatan atas laporan } \\
\text { keuangan dan segala informasi } \\
\text { yang di perlukan dalam penyajian } \\
\text { secara wajar }\end{array}$ & $\begin{array}{l}\text { PSAK No } 101 \text { meliputi rician } \\
\text { mengenai catatan artas laporan } \\
\text { keuangan pernyataan standar } \\
\text { akuntansi dan segala informasi } \\
\text { yang di perlukan dalam rangka } \\
\text { penyajian secara wajar. }\end{array}$ & Sesuai \\
\hline
\end{tabular}




\begin{tabular}{|l|l|}
\hline Pengungkapan & $\begin{array}{l}\text { Saldo awal dan akhir transaksi } \\
\text { qardh berdasarkan berdasarkan } \\
\text { transaksi yang terjadi selalu di catat } \\
\text { sesuai jumlah yang sebenarnya }\end{array}$ \\
terang
\end{tabular}

Kesimpulan

Berdasarkan penelitian yang telah di lakukan pada PT. Bank BRI Syariah Cabang Lhokseumawe di peroleh kesimpulan sebagai berikut:

1. Pengakuan penerapan standar akuntansi syariah pada Bank BRI Syariah Cabang Lhokseumawe telah sesuai dengan PSAK NO.101. Dimana Investasi dalam bentuk kas di ukur berdasarkan jumlah yang di bayarkan.

2. Pengukuran penerapan standar akuntansi syariah pada Bank BRI Syariah Cabang Lhokseumawe telah sesuai dengan PSAK NO.101. Di mana Bagi hasil yang belum di bayar di akui sebagai piutang.

3. Pencatatan penerapan standar akuntansi syariah pada Bank BRI Syariah Cabang Lhokseumawe telah sesuai dengan PSAK NO.101.Dimana Berpedoman pada Fatwa No.07/-DSN-MUI/1 V200 PSAK No.101

4. Pengungkapan penerapan standar akuntansi syariah pada Bank BRI Syariah Cabang Lhokseumawe telah sesuai dengan PSAK NO.101. Dimana pembagian hasil keuntungan usaha sesuai dengan kesepakatan awal.

\section{Saran}

Berdasarkan hasil analisis dan pembahasan dan beberapa kesimpulan pada penelitian ini saran yang dapat di berikan dalam penelitian ini adalah:

1. Bagi perusahaan

Bank BRI Syariah Cabang Lhokseumawe di harapkan dapat memberikan informasi yang lebih informatif mengenai penerapan standar akuntansi syariah PSAK NO.101 Agar peneliti tidak mengalami kesulitan untuk melakukan peneidentifikasian mengenai pengelolaan transaksi keuangan.

\section{Bagi peneliti selanjutnya}

- Pada Penelitian selanjutnya di harapkan tidak hanya menggunakan data primer agar hasil yang di dapat tidak sebatas kesimpulan wawancara saja tetapi bisa mengunakan data lain,misalnya data sekunder sehingga peneliti dapat mengendalikan dan mengawasi kemungkinan terjadi kesalahan dalam perhitungan.

- Diharapkan dalam penelitian selanjutnya tidak hanya mengunakan standar akuntansi keuangan PSAK NO.101 tapi
Rincian saldo qard pada awal

dan akhir periode berdasarkan

sumber serta dana yang di terima selama periode laporan berdasarkan jenisnya.

juga standar akuntansi keuangan lain seperti standar akuntansi keuangan PSAK NO.59 yang mengatur mengenai akuntansi perbankan syariah.

- Penelitian selanjutnya di harapkan tidak hanya berfokus pada satu bank saja yaitu di BRI Syariah Cabang Lhokseumawe tapi mengunakan objek Bank syariah lain untuk mengetahui sejauh mana penerapan standar akuntansi keuangan pada perbankan syariah.

\section{Daftar Pustaka}

Adnan M.Akhyar Kajian karakter akuntansi syariah Jurnal Akuntansi universitas jember 2014

Anonymous Deil Dewan Standar Akuntansi TerbitkanPSAK http//www.republika.co.id/Ko ran_detai316354\&kal_id $=\mathbf{2 5}$ 6/200/12/(Diakses pada 26 februari 2012)

Diyana Al Barra "Evaluasi Akuntansi Praktik Penghimpunan Dana dan Pembiayaan di BMT Yogyakart (studi kasus pada bmt arthamulia insani dan bmt al-ikhlas yogyakarta)", Skripsi Strata1, Fakultas Ekonomi UII, Yogyakarta,2016

Dustirawati“ Perbandingan pengakuan pendapatan antara pembiayaan mudharabah dan pembiayaan musyarakah pada bank syariah" jurnal ekonomi terapan 2011

Junaidi Siska AF "Pelaksanaan Bagi Hasil Dalam Penyaluran Dana Mudharabah Pada Bank Syariah Mandiri (Study di Bank Syariah Mandiri Kudus), TESIS, Universitas Diponegoro, Semarang.) "2006

R.Ait Novatiani,Dkk'Peranan standar akuntansi syariah dalam pengelolaan transaksi 
keuangan syariah”. Jurnal ekonomi dan bisnis terapan 2009

Rina Nuraina Dkk"Pengaruh penerapan pernyataan standar akuntansi keuangan PSAK No.101tentang penyajian laporan keuangan syariah terhadap pengelolaan transaksi keuangan pada bank syariah". Jurnal proseding penelitian SpeSIA 2015

Sejarah

BMT, Indonesia http://www.rahasiasunnah. com/

85/sejarah-bmt diindonesia. htm (diakses pada 26 februari 2012)

Susiana Nuraini "Analisis Pembiayaan Mudharabah pada PT.Bank Tabungan Negara (Persero) Tbk. Kantor Cabang malang”,Skripsi Strata1,Universitas Islam Negeri Maulana Malik Ibrahim, Malang 2010

Syarifudin Amirulah" pengelolaan transaksi keuangan bank syariah PSAK 101."Jurnal akuntansi syariah, 2005

Wasila Neni Hamid "Peranan standar akuntansi syariah dalam penegelolaan transaksi keunagan pada bank syariah" Jurnal ekonomi terapan, 2002

Wangsa sugianto“Analisis pengukuran pendapatan pada bank konvensional dan bank syariah .Jurnal ilmiah akuntansi nomor 06 tahun ke 2 universitas Maranata 
